\title{
Penanggulangan Krisis Air Bersih Dengan Membuat Perpipaan Di Desa Bogori Kalimantan Barat
}

\author{
Yosefina Finsensia Riti*, Putri Puryundari \\ ${ }^{1}$ Fakultas Teknik, Universitas Katolik Darma Cendika \\ email: yosefina@ukdc.ac.id \\ ${ }^{2}$ Fakultas Ekonomi, Universitas Katolik Darma Cendika \\ email: putri.puryundari@ukdc.ac.id
}

\begin{abstract}
Bogori Village is a village located in Serawai District, Sintang Regency, West Kalimantan Province. Bogori village has many rivers but the water is dirty. These rivers cannot be used as a source of drinking water or as a source of other clean water. In addition, Bogori Village is an inland area that cannot be reached by PDAM so that all activities rely on clean springs from Ansar springs. The distance from the Ansar spring from the village center is $\pm 10 \mathrm{~km}$ with a dirt road route that passes through several hills. Therefore, community service is carried out in the form of procurement and distribution of clean water. The activity is technically in the form of installing a new paralon pipe from the Ansar spring. The stages in this activity are holding a discussion forum with residents regarding the need for clean water, surveys to locations that will be the installation points for paralon pipes, and the process of installing paralon pipes carried out with local residents. The result of this service is that water is successfully flowed from the Anzar spring to every hamlet in Bogori Village, namely Sinar Nyangai Hamlet, Keranjik Hamlet, Karangan Panjang Hamlet, and Batu Punjung Hamlet. This makes it easier for the community to get clean water without traveling long distances to fetch water in Batu Punjung Hamlet. All activities went smoothly, as seen from the enthusiasm of the residents in a series of service activities.
\end{abstract}

Keywords: clean water sources, water piping, Bogori village

\begin{abstract}
Abstrak
Desa Bogori merupakan desa yang berlokasi di Kecamatan Serawai, Kabupaten Sintang, Propinsi Kalimantan Barat. Desa Bogori memiliki sungai-sungai yang banyak namun airnya kotor. Sungai-sungai tersebut tidak bisa dimanfaatkan sebagai sumber air minum maupun sebagai sumber air bersih lainnya. Selain itu, Desa Bogori merupakan daerah pedalaman yang tidak dapat dijangkau oleh PDAM sehingga seluruh aktifitas mengandalkan sumber mata air bersih dari mata air Ansar. Jarak tempuh mata air Ansar dari pusat desa $\pm 10 \mathrm{~km}$ dengan rute jalan tanah yang melewati beberapa bukit. Oleh karena itu dilakukan pengabdian masyarakat dalam bentuk pengadaan dan pendistribusian air bersih. Kegiatan tersebut secara teknis berupa pemasangan pipa paralon yang baru dari sumber mata air Ansar. Tahapan dalam kegiatan tersebut adalah mengadakan forum diskusi bersama warga terkait kebutuhan air bersih, survei ke lokasi yang akan menjadi titik pemasangan pipa paralon, dan proses pemasangan pipa paralon yang dilakukan bersama warga masyarakat setempat. Hasil dari pengabdian ini adalah air berhasil dialirkan dari mata air Anzar ke setiap dusun di Desa Bogori yaitu Dusun Sinar Nyangai, Dusun Keranjik, Dusun Karangan Panjang, dan Dusun Batu Punjung. Hal ini memudahkan masyarakat untuk mendapatkan air bersih tanpa menempuh perjalanan yang jauh untuk mengambil air di Dusun Batu Punjung. Seluruh kegiatan berjalan dengan lancar, terlihat dari antusias warga dalam rangkaian kegiatan pengabdian.
\end{abstract}

Kata Kunci: sumber air bersih, perpipaan air, desa Bogori 


\section{PENDAHULUAN}

Air merupakan unsur alam yang sangat penting bagi kehidupan mahkluk hidup, baik manusia, hewan, dan tumbuhtumbuhan [1][2]. Prioritas kebutuhan air terdiri dari dua bagian yaitu kebutuhan air domestik dan non domestik [3][4]. Kebutuhan air domestik yaitu kebutuhan air diperlukan oleh rumah tangga diantaranya keperluan minum, masak, mandi, mencuci pakaian, dan lain-lain[5]. Sedangkan keperluan non domestik yaitu kebutuhan air yang diperlukan di kantor, tempat ibadah, niaga, dan lain-lain. Kondisi sumber air dari setiap daerah berbeda-beda tergantung dari kondisi dan aktifitas masyarakat [6].

Penyediaan air bersih kepada masyarakat berperan dalam meningkatkan lingkungan atau kesehatan masyarakat, mengurangi jumlah orang dengan penyakitnya, terutama penyakit yang berhubungan dengan air, dan juga berperan penting dalam meningkatkan standar atau tingkat kualitas hidup. Penyediaan air adalah tersedianya air minum dalam jumlah yang cukup untuk kebutuhan pemukiman [7].

Desa Bogori adalah salah satu desa di Kalimantan Barat yang memiliki masalah dalam kebutuhan air bersih domestik yaitu pendistribusian air yang sangat terbatas. Sampai saat ini, penyediaan air bersih bagi masyarakat masih dihadapkan pada beberapa masalah yang kompleks dan belum sepenuhnya dapat diatasi. Desa Bogori merupakan daerah pedalaman yang terdiri dari 4 dusun dan tidak dapat dijangkau oleh PDAM sehingga mengandalkan sumber mata air bersih yang jaraknya jauh dari pusat desa yaitu \pm $10 \mathrm{~km}$ dari pemukiman dengan rute jalan tanah yang melewati beberapa bukit. sejak 2010 Pemerintah Desa telah membuat perpipaan dari sumber mata air dan di distribusikan ke setiap dusun. Disetiap dusun mendapatkan 1 keran air. Kondisi sumber air Ansar hanya menggunakan bendungan dengan kedalaman $\pm 1 \mathrm{M}$ dan jarang dibersihkan. Terkadang terjadi penyumbatan di pipa paralon karena masuknya sampah dedaunan dan ranting. Untuk debet air dari sumber air ke keran setiap dusun 1 liter per menit karena jarak yang cukup jauh dan pipa paralon melewati bukit. Terkadang air tidak mengalir dikarenakan ada pipa yang terputus bahkan ada pipa paralon yang pecah sehingga air tidak mengalir selama 1-2 minggu.

Sejak 2012 keran-keran air disetiap dusun sudah tidak berfungsi lagi dan hanya satu titik keran air bersih hanya satu didesa begori yaitu di jembatan dusun batu punjung. Jadi masyarakat mengambil air bersih menggunakan jirigen dari rumah ke keran tersebut. Bagi masyarakat yang memiliki perekonomian diatas rata-rata, mereka membeli selang air yang di sambungkan dari titik pendistribusian ke rumah mereka. Debit air 1 liter per menit. Pada pemerintahan kepala desa Begori saat ini perpipaan air bersih sudah masuk dalam program kerja tetapi tetap terhalang oleh dana.

Oleh karena itu program pengabdian kepada masyarakat dilakukan untuk menyelesaikan permasalahan masyarakat di Desa Begori dalam pendanaan perpipaan air bersih dan proses pembangunan perpipaan yang dilakukan bersama perangkat desa dan kegiatan gotong royong oleh masyarakat.

\section{METODE PENGABDIAN}

Kegiatan pengabdian masyarakat ini dilakukan pada bulan februari hingga juni 2021 diawali dengan analisis kebutuhan warga di Desa Begori melalui diskusi bersama perangkat desa, masyarakat, dan remaja. Setelah mendapatkan program yang tepat dengan banyak pertimbangan, maka kegiatan dimulai dari perencanaan program, pembentukan panitia, pencarian dana, serta proses pembangunan pipa air bersih secara gotong royong.

Metode pelaksanaan yang dilakukan untuk melaksanan program kegiatan 
pengabdian masyarakat terkait pendistribusian air bersih dengan perpipaan di Desa Bogori Kecamatan Serawai, Kabupaten Sintang, Propinsi Kalimantan Barat, yaitu:

1) Forum Group Discussion (FGD)

Forum group discussion adalah metode yang digunakan untuk mendapatkan informasi maupun data mengenai program yang tepat sasaran untuk masyarakat desa Begori dan yang memiliki manfaat jangka panjang. Sehingga dengan data yang dioperoleh dari FGD tersebut akan ditindaklanjuti dalam pelaksanaan program yang akan dijalankan bersama perangkat desa dan masyarakat.

2) Survei

Survei adalah metode yang digunakan dalam melaksanakan kegiatan pengabdian masyarakat di desa Begori yang bertujuan untuk mengumpulkan informasi tentang variabel dari sekelompok objek (populasi). Survei dilakukan ke beberapa remaja, perangkat desa, dan beberapa masyarakat guna mengetahui apa yang sebenarnya dibutuhkan oleh masyarakat desa dan yang sedang diperjuangkan oleh perangkat desa. Survei juga dilakukan dengan berkunjung ke dusun-dusun dan pusat air bersih untuk mengetahui titik-titik perpipaan air yang sesuai.
3) Gotong Royong Pemasangan Perpipaan

Gotong royong dilakukan untuk proses pembangunan atau pemasangan pipa air mulai dari sumber air bersih Ansar hingga ke dusun-dusun. Gotong royong tersebut dilakukan bersama perangkat desa dan masyarakat Desa Bogori.

\section{HASIL DAN PEMBAHASAN}

Program pengabdian masyarakat yang dilakukan oleh tim berawal dari analisis sosial dengan berkunjung ke lokasi lalu berdiskusi bersama perangkat desa, masyarakat, dan remaja. Diskusi pertama dilakukan bersama beberapa remaja untuk berdiskusi mengenai hal sangat dibutuhkan di desa begori dari sudut pandang remaja. Desa Begori belum dijamah oleh PLN, PDAM, hingga menara signal telpon. Hasil diskusi diputuskan dengan pengadaan dan pendistribusian air bersih. Diskusi yang kedua dilakukan bersama masyarakat yang ada di dusun Batu Punjung dan sekitarnya. Menurut masyarakat, yang sangat dibutuhkan adalah air bersih. Kualitas air yang ada di sungai sekitar desa sangat memprihatinkan dan tidak layak untuk di konsumsi. Masyarakat menyarankan untuk fokus pada pendistribusian air bersih menggunakan sistem perpipaan agar masyarakat tidak bergantung pada satu sumber keran yang masih aktif serta mempermudah akses masyarakat mengambil air. Setelah mendapatkan saran dan masukan dari remaja dan masyarakat, maka diskusi terakhir dilakukan bersama perangkat Desa Begori untuk membahas program pengabdian masyarakat dan membentuk panitia kecil. Perangkat desa yang hadir saat rapat kecil tersebut ialah Sekretaris Desa, Ketua BPD, Kaur, Kepala Dusun Batu Punjung dan Kepala Dusun Sinar Nyangai. Pertama tim menjelaskan maksud dan tujuan dari kegiatan pengabdian dan memberitahukan hasil diskusi yang telah dilakukan bersama remaja dan masyarakat setempat. Perangkat desa menyetujui program perpipaan air bersih. Hasil diskusi mengenai program yang sesuai dengan kebutuhan masyarakat dapat di lihat pada Tabel 1.

Tabel 1. Hasil Diskusi Program kegiatan yang Diperlukan

\begin{tabular}{|l|l|l|l|}
\hline $\begin{array}{l}\text { N } \\
\text { o }\end{array}$ & Kategori & $\begin{array}{l}\text { Program } \\
\text { yang } \\
\text { Diusulkan }\end{array}$ & $\begin{array}{l}\text { Hasil } \\
\text { Keputusan }\end{array}$ \\
\hline
\end{tabular}




\begin{tabular}{|l|l|l|l|}
\hline \hline 1 & Remaja & $\begin{array}{l}\text { Menara } \\
\text { pemancar } \\
\text { sinyal } \\
\text { telepon } \\
\text { Distribusi } \\
\text { Air Bersih }\end{array}$ & $\begin{array}{l}\text { Distribusi } \\
\text { Air Bersih }\end{array}$ \\
\hline 2 & $\begin{array}{l}\text { Masyarak } \\
\text { at }\end{array}$ & $\begin{array}{l}\text { Distribusi } \\
\text { Air Bersih }\end{array}$ & $\begin{array}{l}\text { Distribusi } \\
\text { Air Bersih }\end{array}$ \\
\hline 3 & $\begin{array}{l}\text { Perangkat } \\
\text { Desa }\end{array}$ & $\begin{array}{l}\text { Distribusi } \\
\text { Air Bersih }\end{array}$ & $\begin{array}{l}\text { Distribusi } \\
\text { Air Bersih }\end{array}$ \\
\hline
\end{tabular}

Program distribusi air bersih di desa Begori ditargetkan akan dimulai awal bulan mei hingga pertengahan juni.

Target pelaksanaan program kegiatan pengabdian oleh tim dapat di lihat pada Tabel 2.

\begin{tabular}{|l|l|l|l|}
\hline $\begin{array}{l}\text { N } \\
\text { o }\end{array}$ & Dusun & Target & Indikator \\
\hline 1 & $\begin{array}{l}\text { Sinar } \\
\text { Nyangai }\end{array}$ & $\begin{array}{l}\text { Pemasangan } \\
\text { Pipa Paralon }\end{array}$ & $\begin{array}{l}\text { Berhasil } \\
\text { dipasang } \\
\text { dan air } \\
\text { mengalir }\end{array}$ \\
\hline 2 & $\begin{array}{c}\text { Karangan } \\
\text { Panjang }\end{array}$ & $\begin{array}{l}\text { Pemasangan } \\
\text { Pipa Paralon }\end{array}$ & $\begin{array}{l}\text { Berhasil } \\
\text { dipasang } \\
\text { dan air } \\
\text { mengalir }\end{array}$ \\
\hline 3 & Keranjik & $\begin{array}{l}\text { Pemasangan } \\
\text { Pipa Paralon }\end{array}$ & $\begin{array}{l}\text { Berhasil } \\
\text { dipasang } \\
\text { dan air } \\
\text { mengalir }\end{array}$ \\
\hline
\end{tabular}

Tabel 2. Target Program Pemasangan Pipa

$$
\text { Air }
$$

Pelaksanaan program kegiatan pendistribusian air bersih dimulai dari membeli pipa induk, lalu pemasangan pipa mulai dari sumber mata air Ansar. Dari bendungan Ansar air dialirkan menggunakan pipa induk menuruni bukit. Selanjutnya pipa induk dipasang mulai dari kaki bukit melewati kebun sawit sapanjang 7 KM. Saat tiba di jalan propinsi, pipa induk dibuat bercabang dua. Cabang pertama mengarah ke Sungai
Barahie dan cabang yang kedua mengarah ke jalan Propinsi yang akan menuju dusun Karangan Panjang. Pada cabang yang pertama pipa dipasang dari Sungai Barahie ke Dusun Sinar Nyangai dengan jarak $\pm 2 \mathrm{KM}$, dan juga dipasang pipa paralon yang menuju ke sungai Keranjik dengan jarak tempuh \pm 2 KM. Dari sungai keranjik kemudian dipasang pipa menuju dusun batu punjung dengan jarak $\pm 2 \mathrm{KM}$. Pada cabang yang kedua pipa dipasang dari jalan propinsi menuju dusun Karangan Panjang dengan jarak $\pm 3 \mathrm{KM}$.

Gambar 1 berikut menunjukkan dena pemasangan pipa parolon dari bendungan Ansar ke masing-masing dusun. Dari gambar 2 hingga gambar 4 dapat dilihat proses pemasangan pipa hingga tersedianya keran air di setiap dusun.

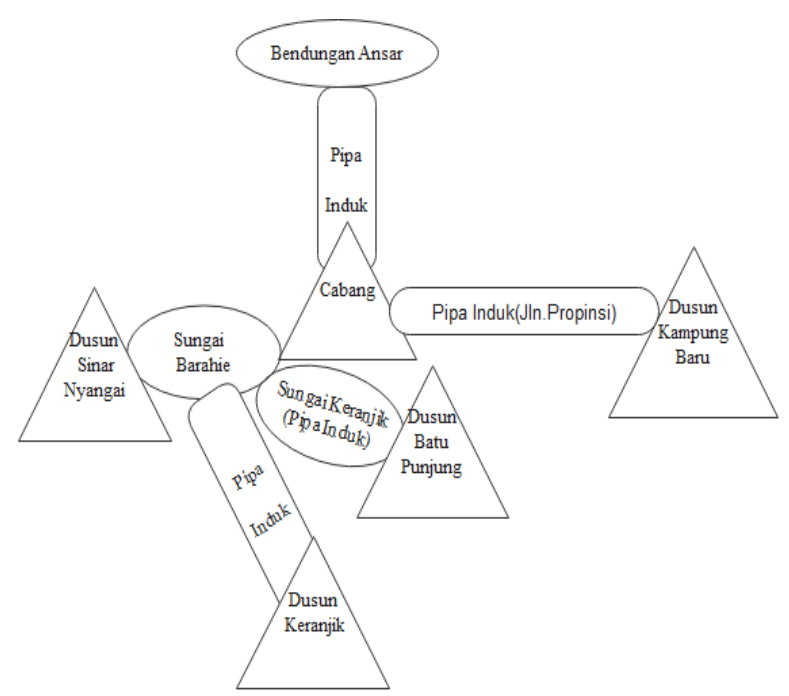

Gambar 1. Dena Pemasangan Pipa Air

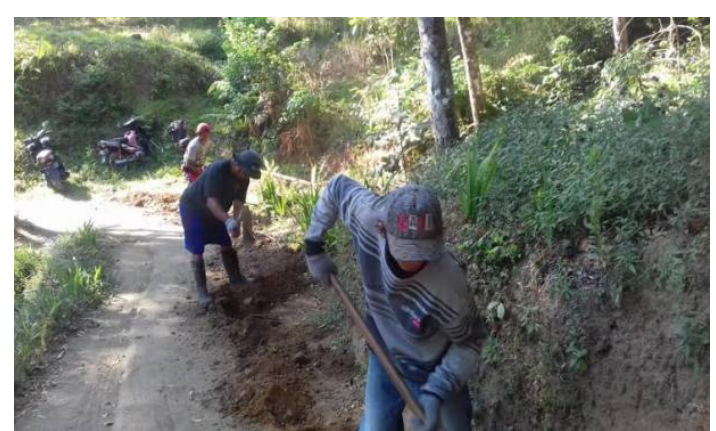

Gambar 2. Penggalian untuk Pipa Air (Jln.Propinsi) 


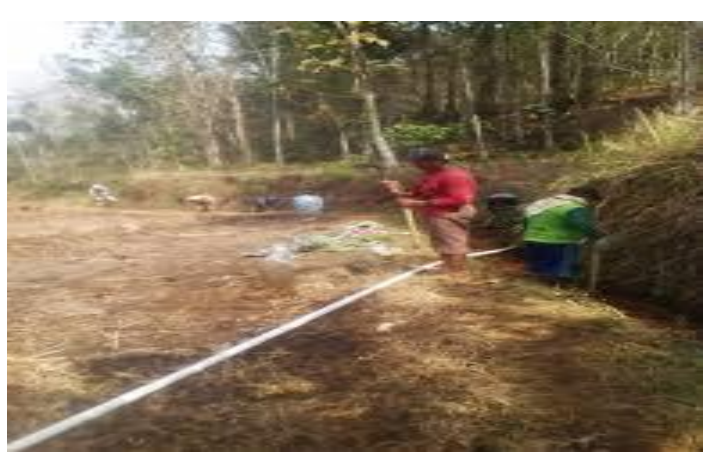

Gambar 3. Pemasangan Pipa Air (Dusun Keranjik)

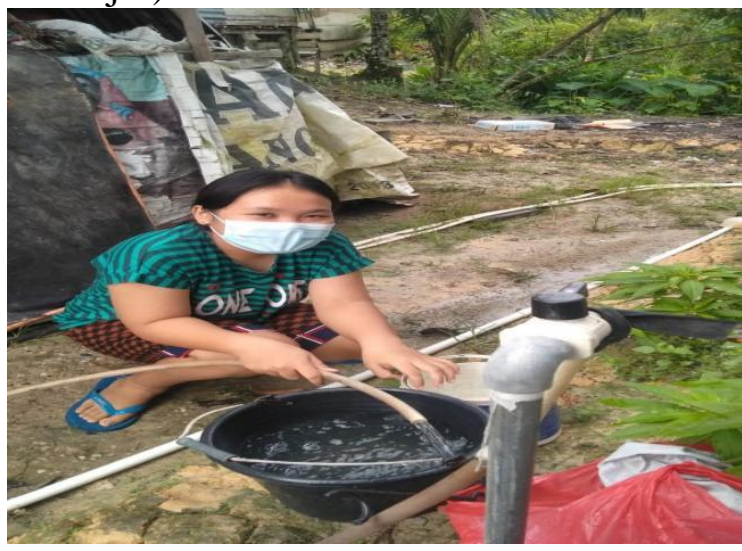

Gambar 4. Keran Air sudah Mengalir (Dusun Sinar Nyagai)

Pemasangan pipa dilaksanakan swadaya oleh pengurus dan masyarakat. Penggalian serta pemasangan pipa yang berada dijalan propinsi dilaksanakan sejak tanggal 3 juni hingga 10 juni 2021. Untuk jalur sungai Barahie kerusakan pipa tidak terlalu parah, hanya 4 batang pipa yang patah karena terjangan derasnya air saat musim penghujan. Pemasangan pipa hingga ke dusun sinar nyangai dan keranjik dilaksanakan mulai dari tanggal 11 juni hingga 13 juni 2021. Proses penggalian dan pemasangan dilakukan oleh masyarakat dengan jumlah pekerja lapangan yang terlibat sebanyak 12 orang.

Dampak yang dirasakan masyarakat dari kegiatan pengabdian ini adalah telah terpasangnya pipa air di Dusun Sinar Nyangai, Dusun Keranjik, dan Dusun Karangan Panjang. Hal ini memudahkan masyarakat untuk mendapatkan air bersih tanpa menempuh perjalanan yang jauh untuk mengambil air di Dusun Batu Punjung. Selain itu dampak lain yang dirasakan oleh masyarakat yaitu terjalinnya rasa kebersamaan dan kerjasama yang lebih baik.

Untuk keberlanjutan program perpipaan ini diharapkan masyarakat Desa Begori dapat menjaga serta merawat pipa air yang telah dibangun dan menjunjung tinggi kegiatan gotong royong.

\section{SIMPULAN}

Kegiatan pengabdian masyarakat mengenai pendistribusian air bersih dengan membangun perpipaan berjalan dengan lancar. Seluruh aktivitas didukung penuh oleh masyarakat dan perangkat desa. Hal tersebut dapat dilihat dari keikutsertaan masyarakat dimulai dari proses diskusi hingga proses pemasangan pipa air. Pemasangan pipa yang dilakukan mencapai target, dimana pipa air telah tersedia di setiap dusun yaitu dusun Sinar Nyagai, dusun Karangan Panjang, dan dusun Keranjik. Total panjang pemasangan pipa yang dilakukan oleh tim pengabdian masyarakat adalah $\pm 16 \mathrm{KM}$. Dari sudut pandang warga Desa Begori, kegiatan ini sangat bermanfaat bagi mereka karena jarak sumber air bersih sudah menjadi lebih dekat. Untuk menjaga keberlanjutan program perpipaan, maka warga diharapkan menjaga serta merawat pipa air yang telah dipasang, Sehingga ketersediaan akan air bersih tetap terpenuhi.

\section{UCAPAN TERIMAKASIH}

Ucapan terimakasih diberikan kepada warga desa yang sudah mendukung kegiatan pengabdian masyarakat ini, dan juga kepada donatur serta perangkat desa sehingga proses pemasangan pipa untuk pendistribusian air bersih dapat terlaksana dengan baik.

\section{DAFTAR PUSTAKA}

[1] D. N. Admadhani, A. Tunggul, S. Haji, and D. Susanawati, "Analysis of Water Supply and Water Demand for Carrying Capacity Assessment ( 
Case Study of Malang )," J. Sube. Alam dan Lingkung., pp. 13-20, 2012.

[2] P. Bagas et al., "Penyediaan Air Bersih Masyarakat Sungapan II dengan Penyaringan Air Sederhana," Pros. Konf. Pengabdi. Masy., vol. 1, pp. 483-485, 2019.

[3] D. S. Krisnayanti, I. M. Udiana, and H. J. Benu, "Studi Perencanaan Pengembangan Penyediaan Air Bersih di Kecamatan Kupang Timur Kabupaten Kupang," vol. II, no. 1, pp. 71-86, 2021.

[4] A. Asta, "Analisis Kebutuhan Air Bersih Dan Distribusi Jaringan PDAM Persemaian Kota Tarakan (Studi Kasus Kecamatan Tarakan Barat)," Borneo Eng. J. Tek. Sipil, vol. 2, no. 1, p. 61, 2018, doi: 10.35334/be.v2i1.613.

[5] D. Nepo, K. Tanasitolo, and K. Wajo, "ABDIMAS Penyuluhan dan Pelatihan Pembuatan Filter Air Bersih di," vol. 24, no. 3, pp. 228232, 2020.

[6] A. Fatah et al., "Krisis Air Bersih dan Peningkatan Ekonomi Mandiri Masyarakat Padukuhan Sarimulyo dengan Paralonisasi," Pros. Konf. Pengabdi. Masy. 1, vol. 1, pp. 1315, 2019.

[7] Syahrani, D. Legono, and F. Nurrochmad, "Analisis Peran Serta Masyarakat Dalam Pengelolaan Air Bersih," Mns. dan Lingkung., vol. XI, no. 2, pp. 86-95, 2004. 